\title{
"Thinking Too Much": Psychological distress, sources of stress and coping strategies of resettled Afghan and Kurdish refugees
}

\author{
C. M. R. Sulaiman-Hill \\ Curtin University of Technology \\ Email: sulaiman.hill@gmail.com
}

\section{S. C. Thompson \\ Curtin University of Technology; University of Western Australia.}

\begin{abstract}
This article outlines the main findings of an exploratory, mixed methods study examining the health and resettlement experiences of predominantly Muslim Afghan and Kurdish refugees in New Zealand and Australia. As post-migration experiences can impact the psychological well-being of already traumatized individuals, this study aimed to identify major sources of stress and describe the coping strategies they use to deal with it. Spending too much time reflecting on past experiences and current international events, separation from family, and feeling overwhelmed by resettlement challenges and concerns were important sources of ongoing stress. High levels of psychological distress and morbidity continued to be observed for some participants, several years after arrival.
\end{abstract}

Keywords: Afghan refugees, Kurdish refugees, resettlement, psychological distress, Muslims, coping strategies, Australia, New Zealand 


\section{"Thinking Too Much": Psychological distress, sources of stress and coping strategies of resettled Afghan and Kurdish refugees}

In recent years, a growing body of international literature has examined factors impacting refugee mental health. Much of the early literature was influenced by trauma psychiatry, with its emphasis on posttraumatic stress disorder (PTSD) and disability. Reported prevalence rates of mental health conditions helped raise awareness of the magnitude of the problem, (De Jong, Komproe, \& Van Ommeren, 2003; Gerritsen et al., 2006; Steel et al., 2009). Although significant morbidity is associated with pre-migration trauma and torture experiences (Silove et al., 2006), post-migration influences including detention (Steel et al., 2006) have also been shown to contribute to posttraumatic stress symptoms (Steel, Silove, Bird, McGorry, \& Mohan, 1999). More recently, much of the research focus has shifted to the post-migration period, exploring links between the early settlement phase and psychological wellbeing. In particular, the additional stresses and systematic constraints facing refugee arrivals, such as socioeconomic circumstances, poor housing, barriers to work and social welfare services, difficulties accessing healthcare, insecurity, and in some cases detention for indefinite periods of time, may compound existing stressors with long term health implications (Ichikawa, Nakahara, \& Wakai, 2006; Silove, Steel, Bauman, Chey, \& McFarlane, 2007; Silove, Steel, \& Watters, 2000; Sinnerbrink, Silove, Field, Steel, \& Manicavasagar, 1997; Steel \& Silove, 2001).

Some critics have expressed concern about the "medicalization of distress" as a pathologic disorder (Summerfield, 1997, p. 1568). They argue that this could distort perceptions about the vast majority of survivors, reducing discussion of refugee issues to psychopathology and objectification of refugee groups (Muecke, 1992). Instead of portraying refugees as passive victims, they could instead be seen as "prototypes of resilience"(Muecke, 1992, p. 515), and the broader social, economic, and political challenges taken into account when assessing their experiences and expressed needs (Watters, 2001). Others have questioned the validity of applying Western concepts of trauma to nonWestern groups, describing links between cultural, religious, and political factors in construction of mental distress (Ruwanpura, Mercer, Ager, \& Duveen, 2006) and a lack of culturally specific considerations have been noted in some studies (Keyes, 2000). In particular, mixed-method studies are recommended to examine the relative influence of current stressors compared with past trauma and the impact on functioning (Tempany, 2009).

At the refugee group level, the collective experience of human rights violations may be reflected in attitudes toward contact between host and refugee culture, with groups from some cultural backgrounds settling better into a new society than others. Majority group attitudes towards migrants, social 
exclusion, and perceptions of discrimination are especially relevant for visibly different groups like Muslims or Africans, and pose particular challenges to resettlement (Casimiro, Hancock, \& Northcote, 2007). In particular, a high prevalence of mental health problems among Afghans and other refugee groups from the Middle East has been documented (Gerritsen et al., 2006; Hosin, Moore, \& Gaitanou, 2006; Miller et al., 2006; Mofidi, Ghazinour, Araste, Jacobsson, \& Richter, 2008; Taloyan, Johansson, Johansson, Sundquist, \& Kocturk, 2006), which may manifest as behavioral shifts or lead to acculturative stress characterized by depression, anxiety, uncertainty, or dysphoria (Allen, Vaage, \& Hauff, 2006; Berry, 2002). Although social support has been shown to enhance coping and promote health, (Ghazinour, Richter, \& Eisemann, 2004; Oppedal, Roysamb, \& Sam, 2004; Simich, Beiser, \& Mawani, 2003) the involuntary nature of the refugee experience predisposes refugees to stress reactions. As the Middle East and Afghanistan continue to feature prominently in current affairs reports, there is an ongoing potential risk of retraumatization for those who have fled conflict situations (Porter \& Haslam, 2005; Sondergaard, Ekblad, $\&$ Theorell, 2001), and, public perceptions of refugees from these regions may be tainted by stereotypes.

In recent years, Australia and New Zealand (NZ) have both accepted refugees from Afghanistan and the Middle East, the two regions currently generating nearly half of all refugees under United Nations protection (UNHCR, 2010). Since 2000, Australia alone has accepted over 58,000 Afghan refugees and New Zealand more than 5000 (UNHCR, 2009), so their long-term settlement outcomes are of ongoing relevance. Both countries have provided dedicated settlement services to humanitarian entrants for many years, with Australia admitting up to 13,000 quota refugees each year $(65 / 100,000$ population/ year), and 750 (19/100,000 population/year) in New Zealand (UNHCR, 2006). A major point of difference between countries, however, is in the number of annual asylum applications, with four times the number per capita received in Australia. In particular, those referred to as 'boat people' in Australia have become the subject of intense public scrutiny and debate over the past decade, with government attempts to curb rising numbers of so-called 'illegal' arrivals resulting in the introduction of policies of mandatory detention and offshore processing in the early 2000s. While many hard-line policies have been reviewed under subsequent governments, asylum seekers continue to arrive, with public opinion polarized regarding how the problem should be managed.

Our mixed methods study aimed to explore resettlement experiences and mental health outcomes, and to identify ongoing sources of stress for former refugees from Afghanistan and the Kurdish regions of the Middle East resettled in new host countries. The presence of established communities of former refugees in Perth, Western Australia, and Christchurch, New Zealand, guided the choice of ethnic groups. The inclusion of the Kurdish groups from Iran 
and Iraq, who share certain similarities with people from Afghanistan, allows opportunities for comparison. The majority are Muslims, many come from traditional backgrounds, they have often suffered persecution as ethnic and/ or religious minorities, and there are still ongoing conflicts in their countries of origin. The main study findings including psychological distress scores and associated morbidity, and major sources of stress and the type of coping strategies used by participants are reported in this article.

\section{Methods}

\section{Study design}

The exploratory study utilized a mixed-methods approach to qualitatively identify major sources of stress, health-seeking, and coping strategies through open ended questions in one-to-one interviews and also to provide a quantitative assessment of psychological well-being in a sample of Kurdish and Afghan former refugees now living in NZ and Australia (KARNZA). This mixed approach helped to contextualize the quantitative findings, explore the impact of psychological distress on functioning, and highlight participants expressed needs and concerns. The study was approved by the Human Research Ethics Committee, Curtin University in Perth, Western Australia.

\section{Participant recruitment and interview procedure}

Study participants were of Afghan or Kurdish ethnicity, 18 years or older at the time of the study in 2008, who arrived in New Zealand or Australia as refugees or asylum-seekers between 1988 and 2008, and were residents of Perth or Christchurch at the time of data collection. Inclusion of participants settled for up to 20 years meant that the Kurdish group in Perth, who mostly arrived during the 1990s, could be included, and also allowed a longer-term focus. Our aim was to recruit 50 participants from each group, to give a total sample of 200. For this exploratory study, given the challenges of recruitment in difficultto-access minority populations such as these (Faugier \& Sargeant, 1997), we aimed for an indicative, rather than truly representative, sample (Colic-Peisker \& Tilbury, 2007).

Snowball sampling was used, with multiple initial contacts within each of the four refugee groups to ensure a spread of people with different backgrounds and experiences (Atkinson \& Flint, 2001; Bloch, 2007; Jacobsen \& Landau, 2003). Short chains of contacts and the application of an informal quote to ensure a range of different Afghan ethnic groups (Hazara, Tajik, Uzbek, etc.) and religious affiliations were included, and helped to reduce selection bias and 
improve representativeness. With the exception of the Christchurch Kurdish community, a small cohesive group which allowed all eligible members to be approached, at least six discrete snowball initiation points were used with each remaining group.

Comparison with 2006 census data from Western Australia for similar ethnic groups, and construction of a 'tentative map' of demographics compiled with assistance from community leaders (Faugier \& Sargeant, 1997), suggests that a reasonably representative sample was recruited. Other research with Iranian groups in Australia has reported comparable demographic profiles to census data using snowball techniques (Khavarpour \& Rissel, 1997; Rissel \& Khavarpour, 1997). A more detailed discussion of the methodological challenges relating to sampling and recruitment in this study is reported elsewhere (Sulaiman-Hill \& Thompson, 2011).

The majority of people participated in individual face-to-face interviews lasting 1-2 hours, and fewer than 10 from the total group of 193 preferred to self-complete the questions and return their responses by mail. The first part of the interview involved completion of the psychometric instruments outlined below, provided in English, Farsi, or Arabic for self-completion or with an interpreter's help if required. In the second part of the interview, open-ended questions were used to direct in-depth discussion of points of interest. These explored resettlement difficulties, perceptions of their personal experience of health and sickness, and their strategies for dealing with stress and ill health. All study materials including information sheets and consent forms were professionally translated into Farsi and Sorani (Kurdish dialect) using standard back-translation methods. Provision of translated materials and access to interpreters allowed people with limited literacy or English language skills to participate.

\section{Instruments}

A full description of the reasons for selection and characteristics of all the study instruments, as well as language considerations, is available elsewhere (Sulaiman-Hill \& Thompson, 2010), but a brief summary is presented here.

Kessler-10 Psychological Distress Scale (K-10)

The main challenge was to select a generalized screening test to measure psychological well-being, which was available in suitably validated and translated versions, in particular Farsi and Arabic, for use with the study communities. The Kessler-10 scale which was developed as a population screening tool for psychological distress, has been used in New Zealand and Australian National 
Health and in state surveys, and is readily available in a selection of suitable languages.

It compares favorably with diagnostic interviews (Composite International Diagnostic Interview; CIDI) and with the General Health Questionnaire12 (GHQ-12) (Andrews \& Slade, 2001). It has also been used with a range of groups from the Middle East (Fassaert et al., 2009).

The Kessler-10 consists of ten questions with five response categories designed to measure psychological distress over the previous four weeks. Each item is scored between 1 (None of the time) and 5 (All of the time), with higher scores indicating more distress. The sum of all ten items gives the total score with a range from 10 to 50 . Missing values are excluded from the total score. There is slight variation in cut-off levels but, for consistency with the NZ and Australian Health Surveys, we used the following criteria: scores of 10-15.9 indicate there is no significant feeling of distress; 16-21.9 indicates an individual may be experiencing moderate levels of distress; 22-29.9 suggests a high level of distress; and scores of 30 or more indicate the possibility of very high or severe levels of distress consistent with a diagnosis of a severe depression and/ or anxiety disorder (Australian Bureau of Statistics, 2007-08; NZ Government, 2008). An additional four questions that do not contribute to the final score are included to assess the impact or degree of disability associated with the identified level of psychological distress. Only people scoring above the minimum are asked to complete these. These questions ask the respondent to identify the following: the number of days in the past four weeks when they have been totally unable to function; the number of days they have needed to cut back on activities of daily life as a result of distress; the number of times they have consulted a health professional in that period; and how many times physical problems have been the main cause of the feelings.

\section{Statistical Analysis}

Descriptive statistics were calculated for K-10 results, as well as sociodemographic variables. Cronbach's alpha was calculated to assess reliability of the instrument, scoring 0.86 for our sample. Kruskal-Wallis and Mann-Whitney U-tests were performed to assess differences between groups of variables. In addition, Kessler-10 data was aggregated into a categorical variable (psych level) based on levels of distress, which were then used to calculate $X^{2}$ statistics for subjective morbidity, reasons for distress, and help-seeking. All analyses of quantitative data were performed using SPSS 12.0 (SPSS Inc.), with significance levels of 0.05, unless stated otherwise. Qualitative responses to openended questions were managed using NVivo 8 (QSR International). They were initially coded using open coding in which the data from each question was broken down into distinct units of meaning. The axial coding stage involved 
comparisons of the codes with one another to discover links between the categories, with related categories aggregated to produce the thematic categories reported (Grbich, 1999). Consensus on the themes was achieved by discussion between the researchers and Afghan and Kurdish interpreters.

\section{Results}

A total of 193 adult participants were recruited in Christchurch $(\mathrm{n}=98)$ and Perth ( $\mathrm{n}=95)$, reflecting a good gender balance, age distribution (18-70 years), family size $(1-10)$, time spent as a refugee $(<1-27$ years), and time since resettlement $(<1-20$ years). Only one participant in Perth had spent twenty years or more in a refugee situation prior to resettlement, compared to 36 (29 Kurdish, 7 Afghans) in Christchurch. Ninety participants identified as Afghan and 103 were Kurdish, and $93 \%$ of the sample was Muslim. Education level was determined by the number of years of schooling with less than one year coded as none/minimal, primary 1-6 years, secondary $7-13$ years, and the remainder classified as tertiary level. All 193 participants completed standardized questionnaires and 124 provided qualitative responses to open-ended questions discussed during interview.

\section{Psychological distress (K-10)}

A summary of K-10 scores, for which there were significant differences between demographic groups, is shown in Table 1. No significant differences for psychological distress risk between groups were observed for ethnic community (Afghan [mean 19.8, SD 7.6, $n=90$ ], Kurdish [mean 20.3, SD 7.9, $n=103$ ]); resettlement location (Christchurch [mean 21.6, $S D$ 9.2, $n=98$ ], Perth [mean 18.6, $S D$ 5.5, $n=95]$ ); religion (Muslim [mean 20.0, $S D$ 7.8, $n=180$ ], nonMuslim [mean 21.0, $S D$ 8.5, $n=8$ ]); family size (living alone [mean 19.1, $S D$ 9.9, $n=7$ ], $2-5$ people [mean 19.3, $S D 7.4, n=96$ ], and $6-10$ people [mean 20.9, $S D$ $7.9, n=81$ ]); and time since resettlement (less than 1 year-2 years [mean 20.0, $S D$ 7.0, $n=29$ ], $3-5$ years [mean $21.5, S D 8.8, n=41$ ] , $6-10$ years [mean 21.0, $S D$ 8.7, $n=71$ ] and $11-20$ years [mean 17.0, $S D 4.5, n=51$ ]).

For the total sample, females scored significantly higher K-10 scores than males. Those participants who were unemployed or unable to speak English also had a higher risk of psychological distress. There was a significant difference between the level of education and Kessler-10 scores on the KruskalWallis test, with those having more education reporting lower K-10 scores (lower risk of psychological distress). Further analysis using Mann-Whitney tests for each paired combination of categories indicated that people with only minimal education had significantly higher levels of psychological risk than 
TABLE 1. Variables contributing to significant differences in Kessler-10 scores

\begin{tabular}{llrcrl}
\hline & Variable & $N$ & K-10 Mean & $S D$ & $\begin{array}{l}\text { Test of } \\
\text { significance }\end{array}$ \\
\hline Gender & Male & 100 & 18.5 & 7.2 & \\
& Female & 93 & 21.8 & 8.0 & $U=333.5, Z=-3.40, p .001$ \\
Employment & Working & 89 & 18.1 & 7.2 & \\
status & Not working & 101 & 22.1 & 7.8 & $U=2994.5, Z=-3.97, p .000$ \\
English ability & No English & 27 & 22.9 & 6.8 & \\
& English & 166 & 19.7 & 7.9 & $U=1543.5, Z=-2.59, p .009$ \\
& None/minimal & 17 & 24.5 & 8.0 & \multirow{2}{*}{${ }^{2}(3,183)=13.83, p .003$} \\
Education* & Primary & 25 & 22.8 & 9.3 & \\
& Secondary & 92 & 19.3 & 6.6 & \\
& Tertiary & 59 & 19.0 & 8.2 & \\
& Never married & 55 & 18.2 & 6.4 & $X^{2}(2,191)=7.19, p .027$ \\
& Married & 125 & 20.3 & 7.6 & \\
& Previously married & 11 & 27.0 & 11.1 & \\
\hline
\end{tabular}

Note: Kruskal-Wallis test results were further analysed using Mann-Whitney tests for each paired combination of categories and the Bonferroni correction was applied to determine statistical significance for each variable.

*Education (Bonferroni p.008) - Significant results were observed between None/minimal and Secondary $(U=445.5, Z=-2.64, p .008)$, and None/minimal and Tertiary $(U=209.5, Z=-3.04, p .002)$

${ }^{\star *}$ Marital status (Bonferroni p.017) - Significant results were observed between Never married and Previously married $(U=164, Z=-2.38, p .017)$

those who have had secondary or tertiary-level education. Similarly, results for marital status showed significant differences between those previously married and never married. Some previously married participants had lost spouse in traumatic circumstances and now had sole responsibility for their family, whereas many of the never-married group were in the younger age bracket and still living with extended family, and this is reflected in their lower levels of psychological distress.

Kessler-10 results were further analyzed using a split-file function to assess possible differences by gender or refugee community. Results indicated a significant difference in risk of psychological distress between males who are working (mean 17.0, SD 5.7, $n=67$ ) and not working (mean 22.1, SD 8.9, $n=31$ ), and males who can speak English (mean 18.0, SD 6.8, $n=96$ ) compared with the few who could not (mean 30.3, SD $8.8 n=4$ ). No significant differences were noted for females. The percentage of people employed also differed significantly, with employment associated with higher English ability for both males and females $\left[X^{2}(1,190)=22.4, p<.001\right]$.

\section{Subjective morbidity}

Participants with K-10 scores of 20 or higher were analyzed further for morbidity; whether a physical health problem was the likely cause of the distress; and whether a health professional was consulted. Results from a total of 79 
people ( $41 \%$ of the total sample; 32 males, 47 females; 43 Kurds, 36 Afghans; 32 in Perth, 47 in Christchurch) were used for this analysis.

The number of days that participants were totally unable to manage and days when they needed to cut back on activities was evenly spread across K-10 scores. Almost 79\% of the sample with symptoms reported being totally unable to manage at some time during the previous month (median: females 4 days, males 2 days), although some reported being unable to cope with the activities of daily life for anything up to an entire month. For the number of days of cutting back on normal activities, nearly $70 \%$ reported some limitation, mostly less than 7 days in total (median: females 2 days, males 0 days). However, when the number of days they were unable to cope was compared by distress level, no significant differences were observed.

\section{Reason for distress}

Participants were asked whether any symptom or their distress was due to a physical health reason. A minority (22.5\%) felt their problems were mainly physical, $34 \%$ that symptoms were sometimes physical, and $43.5 \%$ stated that the symptoms were not due to a physical health reason. When compared across psychological distress level categories, there was no significant difference between groups. Many more females (76\%) reported a physical illness or limitation compared with men $\left[35 \% ; X^{2}(1, \mathrm{~N}=62)=10.70, p .001\right]$.

\section{Consultation with health professionals}

The likelihood of visiting a doctor or other health professional differed whether they reported physical, as opposed to mental health reasons for their symptoms $\left[X^{2}(2, \mathrm{~N}=60)=14.6, \mathrm{p} .001\right]$. Only 3 people out of 26 (two males, one female) who believed their symptoms were due to a mental health problem consulted a health professional about them. Differences between groups reporting mental or physical reasons were significant for women, but not for men $\left[X^{2}(1, \mathrm{~N}=31)\right.$ $=4.21, p .040]$. The percentage of people consulting a doctor about their symptoms also differed by psychological risk level category $\left[X^{2}(2, N=61)=7.40\right.$, p.025], with $75 \%$ of the moderate risk category, $79 \%$ high risk, and $43 \%$ of severe risk groups, not seeking professional medical advice.

Comparison with population data sets

K-10 scores for psychological distress were compared with findings from both New Zealand (2006-07) and Australian (2007-08) health surveys. To allow comparison with KARNZA, K-10 scores were aggregated into low risk (K-10 10-15.9), moderate (K-10 16-21.9), high (K-10 22-29.9) and very high (K-10 
TABLE 2. Comparison of KARNZA K-10 Psychological distress with Australian and New Zealand national surveys

\begin{tabular}{lccc}
\hline & $\begin{array}{c}\text { Low risk } \\
\text { distress } \\
\%\end{array}$ & $\begin{array}{c}\text { Moderate risk } \\
\text { distress } \\
\%\end{array}$ & $\begin{array}{c}\text { High/very high } \\
\text { risk distress } \\
\%\end{array}$ \\
\hline KARNZA New Zealand & 33.7 & 22.4 & 43.9 \\
New Zealand population & 78.7 & 14.7 & 6.6 \\
KARNZA Australia & 33.7 & 46.3 & 20.0 \\
Australian population & 67.3 & 20.6 & 12.0 \\
\hline
\end{tabular}

K-10 psychological distress categories: Low risk 10-15.9, Moderate risk 16-21.9, High risk 22-29.9, Very high risk 30-50

30 or higher) risk categories with the results displayed in Table 2. The major disparity in results between Australian and New Zealand refugee participants is likely to reflect differences in resettlement time, as all people in the 11-20 year group were living in Perth. However, levels of psychological distress remained well above those of national population distribution in both New Zealand and Australia.

\section{Major sources of stress}

Participants were asked to discuss causes of ill health, particularly their mental health, to determine major ongoing sources of stress during the qualitative part of the interview. Responses were classified into nine themes (Table 3); themes reported by the majority of participants responding to this question, reflected ongoing psychological difficulties related to past experiences, retraumatization by current affairs reporting and news from home, too much time to introspect, and generally poor mental health. This theme was termed "Thinking too much", a common descriptor used by study participants for introspection and depressive and anxiety symptoms. Separation from family, especially those still in conflict settings, was another major source of stress, often closely related to news from home, as described in the first theme.

Results were further analyzed by gender. For males, a majority described "thinking too much" as the main stressor, with separation having a negative impact on many in the group. Feeling overwhelmed was also experienced by a number of male respondents. "Thinking too much" was also the main concern for females, but separation was relatively more important than for males. A similar proportion of males and females felt overwhelmed and constrained in their lives. Stressors identified by women more than males included disempowerment, status dissonance, and social isolation. In some cases, this was related to unfulfilled expectations, as described by one woman who had always wanted to be a teacher in Afghanistan. Although the educational opportunities are now available in New Zealand, without family support for childcare she is still unable to fulfill her dream. 
TABLE 3. Major sources of stress in order of prevalence

\begin{tabular}{|c|c|c|}
\hline Theme & Distinguishing Feature & Illustrative Quotes \\
\hline 'Thinking too much' & $\begin{array}{l}\text { Past experiences \& current } \\
\text { reminders/re-traumatisation, } \\
\text { time to introspect at home, } \\
\text { generally sad/unhappy/ } \\
\text { depressed }\end{array}$ & $\begin{array}{l}\text { In Afghanistan there is still a lot of fighting. } \\
\text { When we look at the news I become agitated } \\
\text { "and can't sleep" (AMC } 6 \text { years settled) } \\
\text { "Afghan people suffered a lot, so they have had lots } \\
\text { of fighting and have to fear lots of troubles. All ten } \\
\text { sion is due to lots of unexpected things happening } \\
\text { in Afghanistan (now) and the past" (AFC } 1 \text { year) } \\
\text { "Everything hurts us, this is why we can't learn } \\
\text { things, we are physically in class but the mind is } \\
\text { elsewhere" (AFC } 7 \text { years) }\end{array}$ \\
\hline Separation & $\begin{array}{l}\text { Family, home, past lifestyle, } \\
\text { 'homesick' }\end{array}$ & $\begin{array}{l}\text { "I feel very stressed most of the time } \\
\text { because I am away from my family" (KFP } 6 \text { years) } \\
\text { "We lost very close family members, and our home, } \\
\text { lots of depression and tension" (AFC } 1 \text { year) } \\
\text { "Lots of tension, bad times, away from family; } \\
\text { brother, mother, sister all die at the same time. } \\
\text { This is still a cause of problems now, } 27 \text { years on" } \\
\text { (AMC } 1 \text { year) }\end{array}$ \\
\hline Feeling overwhelmed & $\begin{array}{l}\text { Feeling aimless, hopeless, } \\
\text { no way ahead, daunted by } \\
\text { new life }\end{array}$ & $\begin{array}{l}\text { "People get sick because they can't cope with } \\
\text { differences" (AMP } 15 \text { years) } \\
\text { "Many people feel hopeless" (AMP } 20 \text { years) } \\
\text { "Trying to create a good lifestyle [can affect] } \\
\text { mental instability" (AFP } 17 \text { years) }\end{array}$ \\
\hline Relationships & $\begin{array}{l}\text { Family tensions, community } \\
\text { tensions/pressures, } \\
\text { family power structure, } \\
\text { acceptance in host country }\end{array}$ & $\begin{array}{l}\text { “A lot of people are negative and don't have good } \\
\text { relationships. Many are quite racist and out of } \\
\text { control. They don't have religion or control in their } \\
\text { lives. We come from a collectivist culture [where } \\
\text { people help and support each other]. There are a } \\
\text { lot of problems for young people living here” } \\
\text { (AMP } 20 \text { years) } \\
\text { "It is hard to control children here and parents have } \\
\text { to work too much. Parents here spend their time } \\
\text { working while their children are free [aimless, } \\
\text { getting bad influences]" (AFP } 15 \text { years) } \\
\text { "We want to mix with locals but they don't seem to } \\
\text { want to, they are quite standoffish" (KMC } 3 \text { years) } \\
\text { "Many problems especially dealing with children } \\
\text { and family issues. Big problem for people coming } \\
\text { from the Middle East” (KMC } 6 \text { years) } \\
\text { "Too much freedom here as government will } \\
\text { support children to leave home. This undermines } \\
\text { families" (KMC } 10 \text { years) }\end{array}$ \\
\hline Status dissonance & $\begin{array}{l}\text { Employment, social } \\
\text { position, expectations }\end{array}$ & $\begin{array}{l}\text { "I wanted to be a teacher but I couldn't get the } \\
\text { education (in Afghanistan), and now because of } \\
\text { looking after my children (with no family support) } \\
\text { it is still hard" (AFC } 9 \text { years) } \\
\text { "First generation people can't become professionals } \\
\text { here" (AFP } 17 \text { years) }\end{array}$ \\
\hline
\end{tabular}


TABLE 3.-Continued

\begin{tabular}{|c|c|c|}
\hline Theme & Distinguishing Feature & Illustrative Quotes \\
\hline Disempowerment & $\begin{array}{l}\text { Lack of control, reliance } \\
\text { on others, dependence on } \\
\text { welfare, humiliation }\end{array}$ & $\begin{array}{l}\text { "Some (government department) people were bad } \\
\text { with us, we got upset and it caused health problems, } \\
\text { stress and worry. We felt humiliated by charity" } \\
\text { (AMC } 4 \text { years) } \\
\text { "[Refugees] don't or can't decide about everything, } \\
\text { they can't make decisions" (AMC } 6 \text { years) }\end{array}$ \\
\hline Social isolation & $\begin{array}{l}\text { Language, women, elderly, } \\
\text { housing demographics }\end{array}$ & $\begin{array}{l}\text { "Life is good here, but not for me. I am all alone here" } \\
\text { (KFC } 3 \text { years) } \\
\text { "At home all the time you are sick" (KMC } 6 \text { years) } \\
\text { "No one around you, always at home" (KFC } 3 \text { years) } \\
\text { "Language is really hard, it is difficult to learn English } \\
\text { at my age and I can't drive so it is very difficult to go } \\
\text { out." (KFC } 3 \text { years) }\end{array}$ \\
\hline Cultural/social change & $\begin{array}{l}\text { Social problems } \\
\text { (alcohol, drugs, gangs), } \\
\text { cultural literacy of } \\
\text { government/agency } \\
\text { staff/public }\end{array}$ & $\begin{array}{l}\text { "They (government) shouldn't expect us to change } \\
\text { so soon. The people coming have a very different } \\
\text { culture and religion. How to bridge the gap to not } \\
\text { harm the family, so people can have two cultures" } \\
\text { (AMP } 2 \text { years) } \\
\text { "We have had problems with [indigenous gang] in } \\
\text { our area, our son was hit, chased and attacked" } \\
\text { (KMC } 2 \text { years) } \\
\text { "New Zealand is good, except for beer which } \\
\text { causes a lot of problems" (KMC } 7 \text { years) }\end{array}$ \\
\hline Other & $\begin{array}{l}\text { Immigration detention/ } \\
\text { criminalisation, not } \\
\text { believing in anything/ } \\
\text { economic hardship/ } \\
\text { 'problems' not further } \\
\text { specified }\end{array}$ & $\begin{array}{l}\text { "Life here is safe but the potential opportunities are } \\
\text { hampered by difficulties with language and money. } \\
\text { It is hard to get ahead and we have not progressed } \\
\text { much because of the system. Finances for refugees } \\
\text { are not enough, the system keeps people low" } \\
\text { (KMC } 3 \text { years) } \\
\text { "Previous poor treatment, especially they treated } \\
\text { children like criminals in detention and they still } \\
\text { suffer emotional stress" (AFP } 15 \text { years) }\end{array}$ \\
\hline
\end{tabular}

$\mathrm{A}=$ Afghan, $\mathrm{K}=$ Kurdish; $\mathrm{M}=$ Male, $\mathrm{F}=$ Female; $\mathrm{P}=$ Perth, $\mathrm{C}=$ Christchurch, \& Number of years since arrival

\section{Main issues identified by very high risk distress group}

Interview data from participants identified as having a very high risk of psychological distress were further analyzed to identify any trends in the main stressors reported (Table 4). Twenty-four participants had K-10 scores of 30 or more; $83 \%$ were living in Christchurch, $67 \%$ were Kurdish, $63 \%$ were female, and $21 \%$ were working. They were evenly spread by settlement time (range 1-13 years), time spent as a refugee before resettlement (less than 1 year-27 years), and education level. 
TABLE 4. Main sources of stress for very high risk group (Kessler-10 $\geq 30$ ) - Themes in order of prevalence

\begin{tabular}{|c|c|c|c|}
\hline Theme & Distinguishing Feature & $\begin{array}{l}\text { Mean K-10 } \\
\text { Score }\end{array}$ & $n$ \\
\hline Cultural/Religious & $\begin{array}{l}\text { Lack of respect in society, especially for elders } \\
\text { Culture clash } \\
\text { Wearing Hijab (Muslim headscarf) } \\
\text { Community too small (Kurdish) } \\
\text { Concern that children have influences from } \\
\text { negative Western traditions }\end{array}$ & 35.0 & 11 \\
\hline Resettlement issues/concerns & $\begin{array}{l}\text { Economic - the system keeps people low, } \\
\text { the poor get poorer and there are } \\
\text { many expenses } \\
\text { Housing - shortages, locations (“the area } \\
\text { where we are living has many problems; } \\
\text { our son was hit, chased and attacked. } \\
\text { We would like a house in a nice safe area, } \\
\text { even if the house itself is not as good”) } \\
\text { Transport difficult especially for elderly } \\
\text { when community is fragmented } \\
\text { Perceived discrimination (especially since 9/11) } \\
\text { Security } \\
\text { Not enough support, especially over time } \\
\text { Agencies difficult to deal with }\end{array}$ & 34.3 & 10 \\
\hline Relationships & $\begin{array}{l}\text { Don't trust anyone for personal issues } \\
\text { Easier to mix with other migrants especially } \\
\text { Muslims, than locals } \\
\text { Problems with gangs (see also housing above) } \\
\text { Desire to mix but locals don't }\end{array}$ & 34.6 & 9 \\
\hline Separation & $\begin{array}{l}\text { Struggling with being alone, without family } \\
\text { Can't return home to visit family } \\
\text { Worry about brother still in jail in Iran } \\
\text { Daughters still in Iraqi camps }\end{array}$ & 34.8 & 8 \\
\hline Language/Communication & $\begin{array}{l}\text { Even English speakers have trouble with } \\
\text { communicationi } \\
\text { Inability to express feelings }\end{array}$ & 34.9 & 7 \\
\hline Homesick/Past life/Re-trauma & $\begin{array}{l}\text { Constant worry about family in war zones, } \\
\text { especially in news reports }\end{array}$ & 34.7 & 3 \\
\hline Expectations & $\begin{array}{l}\text { Professionals unable to work } \\
\text { Expectation that life would be better, but } \\
\text { perceived as worse for different reasons } \\
\text { Discouraged by meeting people settled } \\
\text { for many years whose situation hadn't } \\
\text { improved much and who still couldn't } \\
\text { speak English. }\end{array}$ & 35.7 & 3 \\
\hline
\end{tabular}


In comparison with the themes recognized by the general group of participants in Table 3, those in the high risk distress group identified problems more specifically related to resettlement issues. These people are grappling with daily hassles, many of which could be resolved by improved settlement policies and better cross-cultural education of the public. For example, in New Zealand, most refugees are provided with subsidized social housing on arrival if available, but tensions with neighbors, especially in some low socioeconomic areas, has been an ongoing concern and cause of distress for many. In addition, limited social housing stock can result in the need for expensive private rentals; contribute to fragmentation of communities and social isolation. Dependence on welfare payments and the necessity to deal with government agencies is considered humiliating and disempowering. Although efforts to improve cultural competence among government and agency employees are to be applauded, it is often superficial and limited. During data collection, a very experienced agency worker was overheard joking with colleagues that Muslim clients had tried to obtain a prayer rug on their resettlement grant. It seemed beyond her comprehension that such an item would be considered important. When fundamental concerns are dismissed or trivialized, participants described feeling upset and stressed.

Although other cultural and religious tensions with host societies were noted, many of these are not specific to refugees.

\section{Coping strategies}

The majority of participants were aware that many of their physical symptoms related to psychological problems and used the range of coping strategies described in Table 5. Overall, exercise was the most commonly mentioned way of dealing with psychological distress. Although used by both men and women, three quarters of the people discussing exercise were men. Exercise frequently involved getting outside in the fresh air and usually included going for a brisk walk. For some people walking up in the NZ mountains, where they could experience a sense of freedom was particularly helpful. Socializing was the second most common method of handling stress, and it was mainly favored by women (of those who mentioned the importance of social interaction $70 \%$ were female, $30 \%$ male). Over half of the women in the total group interviewed reported discussing their problems with friends or family. Since it was often not considered appropriate to discuss some concerns with men or people outside the direct family group, phoning mothers and sisters overseas on a regular basis was almost universally reported, despite the cost. These family members were able to provide a level of emotional support that was otherwise lacking in their post-resettlement environment. Avoidance strategies and relaxation techniques were used equally by both men and women, however, religious practices 
TABLE 5. Mental health coping strategies reported in order of frequency

\begin{tabular}{ll}
\hline Coping Strategy & Distinguishing Features \\
\hline Exercise & Walking, gardening, get out in fresh air \\
Socialise & Talk to others, phone family back home, visit friends \\
Avoidance & Take mind off problem, keep busy, working, try to step away \\
Relaxation & Sleep, massage, take a shower \\
Religious & Pray, read Qur'an \\
Professional help & Doctor/psychologist/medication \\
$\begin{array}{l}\text { Positive thinking/try to } \\
\text { remedy situation }\end{array}$ & Attempt to change controllable situation, stressor or \\
Insoluble & perception of it \\
\hline
\end{tabular}

such as reading the Qur'an and praying proved particularly important for females (90\% of people who mentioned this were women). These women derived significant inner strength from their religious conviction, which proved helpful when dealing with the public reactions around asylum arrivals and international terrorism. They reported a sense of solidarity and unity with their Muslim sisters, irrespective of their various backgrounds and ethnicities. In contrast, it was interesting to note that seeking professional help, such as visiting a doctor/counselor or taking medication to relieve stress, was only mentioned by male participants.

\section{Discussion}

The present study is exploratory, aiming to assess ongoing sources of stress for resettled refugees and the impact on their mental health status. A comparison with data from New Zealand and Australian health surveys indicates that the levels of psychological distress experienced by participants is considerably higher than the general population in these countries, with over $66 \%$ of former refugees scoring in the moderate, high, or very high risk categories, compared with $21 \%$ and $32 \%$ in the general population in New Zealand and Australia, respectively. This is consistent with previous studies which have reported a high prevalence of mental health concerns among former refugee groups. In particular, we noted significant differences between groups based on gender, with females scoring higher on the distress scale than males, which is also consistent with other research (Miller et al., 2006; Porter \& Haslam, 2005; Schweitzer, Melville, Steel, \& Lacherez, 2006). Unemployment, not being able to speak English, being previously married (either divorced or widowed), and having only minimal education were also associated with an increased risk of psychological distress as reported elsewhere (Beiser \& Hou, 2001; Laban, Gernaat, Komproe, van der Tweel, \& De Jong, 2005; Nwadiora \& McAdoo, 1996). Many of these variables are interrelated: learning English could be more difficult for people 
with limited literacy skills and those with minimal education may have less English at the time of migration, which in turn will impact on employability. In particular, many of the Christchurch Kurdish participants were long-term refugees, spending more than twenty-five years in refugee camps prior to resettlement, and had not had the educational opportunities of some other participants, which may account for some disparities between Kurds in each location. The challenges, especially for older, pre-literate learners from traditional backgrounds, to adapt and succeed in modern, literate societies are immense and observed in our results, although age as a variable was not significant. A meta-analysis of compromised mental health among refugees found those who were older and more educated had worse outcomes (Porter \& Haslam, 2005), findings which differ from the current study which found those with minimal education had higher psychological distress scores.

The description "thinking too much" was used, or understood, by almost all participants when discussing ongoing sources of stress during interview. It encompassed many depressive emotions and anxiety symptoms, as reflected in the K-10 criteria, and was the most common source of concern for both men and women. In nearly all cases, this theme reflected participants having too much time worrying about events overseas or dwelling on past experiences. A previous study with Iraqi and Kurdish participants found they were greatly influenced by political events and the situation of significant others in their home country (Sondergaard et al., 2001). This was also reported in a meta-analysis of 59 comparison studies of refugee mental health, where worse outcomes were observed for those whose initiating conflict was unresolved (Porter \& Haslam, 2005). Similarly, Kira and colleagues (2008) identified an association between war media reporting and physical and mental health problems in Iraqi refugees. They report negative impacts from media exposure that was comparable to the death or serious injury of a family member or friend during the war. Participants in our study also described retraumatization, feelings of helplessness, and anxiety for the safety of family members back home, often in response to news reports and media images. This has been a particular concern for people from Afghanistan and Iraq in recent years and may be exacerbated by public ignorance and insensitivity in host countries. The psychological consequences of this are evidenced by the inability of many people to cope with daily life tasks and difficulties with concentration described. Greater understanding of the issues confronting refugees could enable better educational outcomes. This might be achieved by extending education programs over a longer timeframe to allow people time to adjust and overcome some of their initial resettlement difficulties, or greater flexibility with timetabling of English-language classes so they could study when most receptive. In addition, efforts to assist these refugees to engage in employment, or other meaningful ventures to keep them occupied may help to improve mental health outcomes. 
News from home also often highlights family separation and lack of support, and the impact of this extends over many years. Separation was the second most commonly described stressor, and was more important for females than males. Women are more likely to be at home with young children, less likely to speak English well (85\% of those not speaking English were female), and have greater potential for social isolation. This is compounded if husbands are working long hours to support their immediate family (and frequently also extended family back home). An examination of the coping strategies employed by females suggests the importance of social contact, especially with other women. However, for many people it is not culturally acceptable to discuss private family matters with outsiders, so the lack of contact with close female relatives was a concern for many. Family reunification policies play a crucial role in getting families back together; however, in practice sponsorship is often extended to the husband's relations; potentially further isolating women from their own close family members. In some cases, existing relationships may also fall apart due to the stress of the whole resettlement experience. In these situations, women may become more socially isolated, or even shunned by other community members for the perception that they have failed in their family 'duties' or to uphold cultural norms. The stresses for women in these situations are significant; trying to raise their children alone, socially isolated from their own ethnic community, often unable to speak English well enough to mix comfortably with locals, aware of cultural and religious distance, and reliant on government support for necessities, all impact on their levels of psychological distress.

Several study participants highlighted the problem of status dissonance, conceptualized as a conflict between professional and social expectations and reality. In common with the circumstances of many refugees and other migrants, former professionals and academics are often forced to work in lowpaid and dangerous jobs, which may contribute to a continuing sense of despondency. Many are now driving taxis to make ends meet and maintain some sense of self respect, despite the inherent dangers and exposure to less-desirable elements in society. For example, the high-profile stabbing of an Afghan former refugee taxi driver in Christchurch at the end of 2008 sent shockwaves through the small, close-knit community, highlighting concerns of vulnerability and prompting many to question their long-term settlement realities amid reports that he often felt intimidated by drunken and aggressive customers and faced constant abuse and threats of violence (Anon, 7 December 2008). Discrimination has been reported as a significant stressor in previous studies (Laban et al., 2005; Taloyan et al., 2006), and, apart from this incident which occurred after data collection, most of the negative comments concerning perceived discrimination and derogatory discourses were from Australian participants. In particular, some people mentioned that attitudes to Muslims had changed 
since $9 / 11$, and they felt that this potentially affected their acceptance within the wider society, even after many years. This was seen as a particular issue for women wearing hijab and resulted in many preferring to socialize with other Muslims rather than the general population. The arrival of asylum seekers in Australia has, since 2001, been associated with a hardening of public and political attitudes toward refugees, and this may also contribute to the perception of some participants that they will never really fit in. An examination of the portrayal of Muslims or refugees in the Australian media reveals the extent of this (Sulaiman-Hill, Thompson, Afsar, \& Hodliffe, 2011).

An unexpected finding was that status dissonance and disempowerment were more commonly mentioned by women than by men. We had anticipated that men would be more concerned about obtaining employment appropriate to their previous experience and qualifications, and humiliated by dependence on welfare and social services, but this was only important to few participants. Women, on the other hand, seemed to experience a reversal effect, possibly due to differing expectations in the host country and a change in their traditional roles. Some women, particularly pre-literate learners, found attending classes to be quite stressful especially when it involved trying to juggle housework and child-rearing responsibilities without extended family involvement. The whole social structure of the new host society, lack of family support, changing roles and expectations, social dispersal of ethnic groups around the city and different expectations of neighbors, contribute to a sense of social dislocation for many former refugee women. Some of these effects can be seen in the findings from the highest risk group, which highlight the impact of ongoing resettlement concerns on their mental health. Many of the stressors identified by that group, in particular housing problems, economic challenges, employment difficulties, lack of cultural awareness by agency staff and inadequate long-term support, could be addressed by targeted policies and improved support programs.

In general, the majority of participants identified the factors that impact negatively on their mental health. They were well aware of ongoing sources of stress, and have adopted a range of strategies to enable them to cope. Papadopoulos and colleagues (2004) also document this awareness. We noted a discrepancy between this and a patronizing attitude among some support workers who seem to be oblivious to the underlying reasons for refugees' distress and to consider refugees as ignorant. In our study, most participants were fully aware of the impact of both pre- and post-migration influences on their mental health, but felt many of their problems were insoluble. This is clearly reflected in attitudes towards health-seeking, with many people not obtaining professional help despite considerable morbidity. These findings add support to those reported by Boufous and colleagues (2005) in an Australian study using the same instrument (Kessler-10). They found that people from non-English speaking backgrounds, especially those from South/South East Asia and Af- 
rica/Middle East recorded significantly higher levels of psychological distress and lower levels of health service use. Of note in the current study was that only male participant spontaneously mentioned considering professional help as an option, and only $21 \%$ of men (compared to $48 \%$ of women) in the high risk group actually reported visiting a doctor for any reason. Many of these women attributed their symptoms to a physical problem which may reflect gender differences in somatization (Aragona, Monteduro, Colosimo, Maisano, \& Geraci, 2008). Although it is possible that attitudes to health services may be informed by social mobility or education, no differences in attributing symptoms to a physical as opposed to mental health problem (or whether a doctor was consulted) were noted based on the length of time settled or education level of the women concerned. Skepticism regarding professional support was also noted, with a few participants confessing that they gave mental health professionals the answers they wanted to hear, because they believed their problems could not be resolved and preferred to rely on their own coping mechanisms. Similar findings have been reported by Ruwanpura and colleagues (2006), who detected ambivalence among Tibetan refugees towards the use of Western therapies. Although some participants in their study group adopted a pragmatic, integrative approach to treatment options, their primary coping strategies were linked to culturally relevant family and religious support mechanisms.

This study was exploratory, as a comparative assessment of similar groups in Australia and New Zealand has not previously been attempted. However, a few limitations can be identified. The first relates to methodological challenges, particularly around sampling, which occur with many small-scale refugee research projects. The snowball method used means our results are not generalizable to a wider population, although the personal endorsements inherent in this method (which helped break down barriers and provided reassurance to potentially suspicious participants) ensured a large enough sample for a valid study. This method was particularly successful for recruiting many female refugees, who may decline to participate if approached directly; our strategy of using multiple entry points into each community resulted in a sample with reasonable representativeness based on census data and community-supplied demographic information. Using only Muslim interviewers also helped our credibility, but potentially introduced some social desirability bias as no one mentioned drinking alcohol or taking drugs to alleviate stress, despite anecdotal reports that some people (mostly men) do this. Participants may also be more likely to discuss religious coping mechanisms than they would if interviewed by non-Muslims.

In addition, cut-off points for each instrument should ideally be determined for each cultural group surveyed, so some care needs to be taken with interpretation of Kessler-10 scores (Fischer, 2004; Smith, 2004). In Afghanistan, for example, when high prevalence rates for anxiety and depression (as- 
sessed using standard mental health questionnaires) were compared with a standard psychiatric interview, results indicated that the optimal cut-off points should be higher than usual for women, but lower than normal for men; this suggested that earlier studies may have over- and underestimated prevalence rates respectively (Ventevogel et al., 2007). Although it is beyond the scope of the present study to accurately determine this, mean K-10 scores for men were 18.5 and for women were 21.8 , so even if these were adjusted in line with these findings, means for both men and women would still fall within the moderate risk range, significantly higher than the local populations.

\section{Conclusion}

Our study findings suggest that former refugee participants may suffer from significantly higher levels of psychological distress than the general population, and this was particularly related in our study to poorer English language ability, unemployment status, lower educational level, and female gender. Many reported considerable associated morbidity, being unable to manage or having to cut back on daily activities at some time during the previous month. Most people with symptoms did not seek professional help, but instead relied on their own coping strategies. For the group overall, the main stressors were related to past experiences/current reminders and separation; for those with the worst psychological distress scores, stressors were more tangible and immediate, and frequently related to ongoing resettlement concerns which in many cases could be ameliorated by targeted policies and longer term support. Cultural and religious worries for our predominantly Muslim sample were also of concern, although we were unable to draw any specific religiously based inferences from this study. However, these findings raise important questions about the impact that being a visibly different religious minority may have on an individual's psychological well-being, in two countries with predominantly Christian influences. Further comparative studies examining the impact of visible difference on public attitudes and acceptance of different refugee groups would be of additional value.

\section{Acknowledgements}

Special thanks to all former refugee participants, key informants and interpreters from the Afghan and Kurdish communities in Christchurch and Perth, without whose assistance this study would not have been possible. Thanks to Nasr (Nicholas) Sulaiman-Hill and Sawsan Kamal Ahmad for their help with data collection, also the people and agencies that provided advice around re- 
cruitment. We also wish to acknowledge the statistical support provided by Dr Neilson Martin. The author (CS-H) was supported by an Australian Postgraduate Award scholarship.

\section{References}

Allen, J., Vaage, A., \& Hauff, E. (2006). Refugees and asylum seekers in societies. In D. L. Sam \& J. W. Berry (Eds.), Cambridge Handbook of Acculturation Psychology. Cambridge \& New York: Cambridge University Press.

Andrews, G., \& Slade, T. (2001). Interpreting scores on the Kessler Psychological Distress Scale (K10). Australian and New Zealand Journal of Public Health, 25(6), 494497.

Anon. (7 December 2008). Refugee stabbed to death - Afghan cabbie survived war, persecution and a sinking boat. Sunday News,

Aragona, M., Monteduro, M. D., Colosimo, F., Maisano, B., \& Geraci, S. (2008). Effect of Gender and Marital Status on Somatization Symptoms of Immigrants from Various Ethnic Groups Attending a Primary Care Service. German Journal of Psychiatry, 11, 64-72.

Atkinson, R., \& Flint, J. (2001). Accessing Hidden and Hard-to-Reach Populations: Snowball Research Strategies. Social Research Update 33 Retrieved Dec 2010, from http://sru.soc.surrey.ac.uk/SRU33.html

Australian Bureau of Statistics. (2007-08). National Health Survey: Summary of Results. Retrieved Dec 2010, from http://www.abs.gov.au/ausstats/abs@.nsf/ $\mathrm{mf} / 4364.0 /$

Beiser, M., \& Hou, F. (2001). Language acquisition, unemployment and depressive disorder among Southeast Asian refugees: a 10-year study. Social Science \& Medicine, 53(10), 1321-1334.

Berry, J. (2002). Conceptual approaches to acculturation. In K. M. Chun, P. B. Organista \& G. Marin (Eds.), Acculturation - Advances in Theory, Measurement, and Applied Research. Washington: American Psychological Association.

Bloch, A. (2007). Methodological Challenges for National and Multi-sited Comparative Survey Research. Journal of Refugee Studies, 20(2), 230-247.

Boufous, S., Silove, D., Bauman, A., Steel, Z. (2005). Disability and Health Service Utilization Associated with Psychological Distress: The Influence of Ethnicity. [Journal]. Mental Health Services Research, 7(3), 171-179.

Casimiro, S., Hancock, P., \& Northcote, J. (2007). Isolation and Insecurity: Resettlement Issues Among Muslim Refugee Women in Perth, Western Australia. Australian Journal of Social Issues, 42(1), 55.

Colic-Peisker, V., \& Tilbury, F. (2007). Integration into the Australian Labour Market: The Experience of Three "Visibly Different" Groups of Recently Arrived Refugees International Migration, 45(1), 59-85.

De Jong, J., Komproe, I. H., \& Van Ommeren, M. (2003). Common mental disorders in postconflict settings. [Research letter]. The Lancet, 361, 2128-2130.

Fassaert, T., De Wit, M. A. S., Tuinebreijer, W. C., Wouters, H., Verhoeff, A. P., Beekman, A. T. F., et al. (2009). Psychometric properties of an interviewer-administered version of the Kessler Psychological Distress scale (K10) among Dutch, Moroccan 
and Turkish respondents. International Journal of Methods in Psychiatric Research, 18(3), 159-168.

Faugier, J., \& Sargeant, M. (1997). Sampling hard to reach populations. Journal of Advanced Nursing, 26(4), 790-797.

Fischer, R. (2004). Standardization to Account for Cross-Cultural Response Bias: A Classification of Score Adjustment Procedures and Review of Research in JCCP. Journal of Cross-Cultural Psychology, 35(3), 263-282.

Gerritsen, A., Bramsen, I., Deville, W., van Willigen, L., Hovens, J., \& van der Ploeg, H. (2006). Physical and mental health of Afghan, Iranian and Somali asylum seekers and refugees living in the Netherlands. Social Psychiatry and Psychiatric Epidemiology, 41(1), 18-26.

Ghazinour, M., Richter, J., \& Eisemann, M. (2004). Quality of Life Among Iranian Refugees Resettled in Sweden. Journal of Immigrant Health, 6(2), 71-81.

Grbich, C. (1999). Qualitative research in health: an introduction. Sydney: Allen \& Unwin.

Hosin, A., Moore, S., \& Gaitanou, C. (2006). The Relationship Between Psychological Well-Being and Adjustment of Both Parents and Children of Exiled and Traumatized Iraqi Refugees. Journal of Muslim Mental Health, 1, 123-136.

Ichikawa, M., Nakahara, S., \& Wakai, S. (2006). Effect of post-migration detention on mental health among Afghan asylum seekers in Japan. Australian and New Zealand Journal of Psychiatry, 40, 341-346.

Jacobsen, K., \& Landau, L. (2003). The Dual Imperative in Refugee Research: Some Methodological and Ethical Considerations in Social Science Research on Forced Migration. Disasters, 27(3), 185-206.

Keyes, E. (2000). Mental Health Status in Refugees: An integrative review of current research. Issues in Mental Health Nursing, 21(4), 397-410.

Khavarpour, F., \& Rissel, C. (1997). Mental health status of Iranian migrants in Sydney. Australian and New Zealand Journal of Psychiatry, 31, 828-834.

Kira, I., Templin, T., Lewandowski, L., Ramaswamy, V., Ozkan, B., \& Mohanesh, J. (2008). The Physical and Mental Health Effects of Iraw War Media Exposure on Iraqi Refugees. Journal of Muslim Mental Health, 3(2), 193-215.

Laban, C. J., Gernaat, H. B., Komproe, I. H., van der Tweel, I., \& De Jong, J. T. (2005). Postmigration living problems and common psychiatric disorders in Iraqi asylum seekers in the Netherlands. J Nerv Ment Dis, 193(12), 825-832.

Miller, K. E. P., Omidian, P. P., Quraishy, A. S., Quraishy, N., Nasiry, M. N., Nasiry, S. B. A., et al. (2006). The Afghan Symptom Checklist: A Culturally Grounded Approach to Mental Health Assessment in a Conflict Zone. Amercian Journal of Orthopsychiatry, 76(4), 423-433.

Mofidi, N., Ghazinour, M., Araste, M., Jacobsson, L., \& Richter, J. (2008). General Mental Health, Quality of Life and Suicide-Related Attitudes Among Kurdish People in Iran. International Journal of Social Psychiatry, 54(5), 457-468.

Muecke, M. (1992). New Paradigms for Refugee Health Problems. Social Science \& Medicine, 35(4), 515-523.

Nwadiora, E., \& McAdoo, H. (1996). Acculturative stress among Amerasian refugees: gender and racial differences. Adolescence, 31(122), 477-487.

NZ Government. (2008). A Portrait of Health: Key results of the 2006/07 New Zealand Health Survey. Retrieved Dec 2010, from http://www.moh.govt.nz/moh.nsf/ indexmh/portrait-of-health 
Oppedal, B., Roysamb, E., \& Sam, D. L. (2004). The effect of acculturation and social support on change in mental health among young immigrants. International Journal of Behavioral Development, 28(6), 481-494.

Papadopoulos, I., Lees, S., Lay, M., \& Gebrehiwot, A. (2004). Ethiopian refugees in the UK: Migration, adaptation and settlement experiences and their relevance to health. Ethnicity and Health, 9(1), 55-73.

Porter, M., \& Haslam, N. (2005). Predisplacement and Postdisplacement Factors Associated With Mental Health of Refugees and Internally Displaced Persons: A Metaanalysis. JAMA, 294(5), 602-612.

Rissel, C., \& Khavarpour, F. (1997). An Application of 'Snowball' Sampling Among a Small Dispersed Migrant Population for Health Research. Health Promotion Journal of Australia, 7(3), 196-199.

Ruwanpura, E., Mercer, S. W., Ager, A., \& Duveen, G. (2006). Cultural and Spiritual Constructions of Mental Distress and Associated Coping Mechanisms of Tibetans in Exile: Implications for Western Interventions. Journal of Refugee Studies, 19(2), 187-202.

Schweitzer, R., Melville, F., Steel, Z., \& Lacherez, P. (2006). Trauma, post-migration living difficulties, and social support as predictors of psychological adjustment in resettled Sudanese refugees. Australian and New Zealand Journal of Psychiatry, 40(2), 179-188.

Silove, D., Steel, Z., Bauman, A., Chey, T., \& McFarlane, A. (2007). Trauma, PTSD and the longer-term mental health burden amongst Vietnamese refugees: A comparison with the Australian-born population. Soc Psychiatry Psychiatr Epidemiol, 42, 467-476.

Silove, D., Steel, Z., Susljik, I., Frommer, N., Loneragan, C., Brooks, R., et al. (2006). Torture, Mental Health Status and the Outcomes of Refugee Applications among Recently Arrived Asylum Seekers in Australia. [Journal]. International Journal of Migration, Health and Social Care, 2(1), 4-14.

Silove, D., Steel, Z., \& Watters, C. (2000). Policies of Deterrence and the Mental Health of Asylum Seekers. JAMA, 284(5), 604-611.

Simich, L., Beiser, M., \& Mawani, F. N. (2003). Social support and the significance of shared experience in refugee migration and resettlement. Western Journal of Nursing Research, 25(7), 872.

Sinnerbrink, I., Silove, D., Field, A., Steel, Z., \& Manicavasagar, V. (1997). Compounding of premigration trauma and postmigration stress in asylum seekers. Journal of Psychology, 131(5), 463-470.

Smith, P. (2004). Acquiescent Response Bias as an Aspect of Cultural Communication Style. Journal of Cross-Cultural Psychology, 35(1), 50-61.

Sondergaard, H. P., Ekblad, S., \& Theorell, T. (2001). Self-reported life event patterns and their relation to health among recently resettled Iraqi and Kurdish refugees in Sweden. J Nerv Ment Dis, 189(12), 838-845.

Steel, Z., Chey, T., Silove, D., Marnane, C., Bryant, R., \& Van Ommeren, M. (2009). Association of Torture and Other Potentially Traumatic Events With Mental Health Outcomes Among Populations Exposed to Mass Conflict and Displacement - A Systematic Review and Meta-analysis. JAMA, 302(5), 537-549.

Steel, Z., Silove, D., Bird, K., McGorry, P., \& Mohan, P. (1999). Pathways from War Trauma to Posttraumatic Stress Symptoms Among Tamil Asylum Seekers, Refugees, and Immigrants. [Journal]. Journal of Traumatic Stress, 12(3), 421-435. 
Steel, Z., Silove, D., Brooks, R., Momartin, S., Alzuhairi, B., \& Susljik, I. (2006). Impact of immigration detention and temporary protection on the mental health of refugees. Br J Psychiatry, 188, 58-64.

Steel, Z., \& Silove, D. M. (2001). The mental health implications of detaining asylum seekers. eMJA, 175, 596-5599.

Sulaiman-Hill, C. M. R., \& Thompson, S. C. (2010). Selecting instruments for assessing psychological wellbeing in Afghan and Kurdish refugee groups. BMC Research Notes, 3, 237.

Sulaiman-Hill, C. M. R., \& Thompson, S. C. (2011). Sampling challenges in a study examining refugee resettlement. BMC International Health \& Human Rights, 11(2).

Sulaiman-Hill, C. M. R., Thompson, S. C., Afsar, R., \& Hodliffe, T. L. (2011). Changing images of refugees: A comparative analysis of Australian and New Zealand print media 1998-2008. Journal of Immigrant and Refugee Studies, 9, 345-366.

Summerfield, D. (1997). Legacy of war: beyond "trauma" to the social fabric. The Lancet, 349(9065), 1568.

Taloyan, M., Johansson, L. M., Johansson, S.-E., Sundquist, J., \& Kocturk, T. O. (2006). Poor Self-reported Health and Sleeping Difficulties among Kurdish Immigrant Men in Sweden. Transcultural Psychiatry, 43(3), 445-461.

Tempany, M. (2009). What Research tells us about the Mental Health and Psychosocial Wellbeing of Sudanese Refugees: A Literature Review. Transcultural Psychiatry, 46(2), 300-315.

UNHCR. (2006). Refugees by numbers.

UNHCR. (2009, July). Statistical Online Population Database. Retrieved Nov 2010, from http://unhcr.org/statistics/populationdatabase

UNHCR. (2010, June). 2009 Global Trends: Refugees, Asylum Seekers, Returnees, Internally Displaced and Stateless Persons. Retrieved Nov 2010, from http://www. unhcr.org/4c11f0be9.pdf

Ventevogel, P., De Vries, G., Scholte, W., Shinwari, N., Faiz, H., Nassery, H., et al. (2007). Properties of the Hopkins Symptom Checklist-25 (HSCL-25) and the SelfReporting Questionnaire (SRQ-20) as screening instruments used in primary care in Afghanistan. Soc Psychiatry Psychiatr Epidemiol, 42(4), 328-335.

Watters, C. (2001). Emerging paradigms in the mental health care of refugees. Social Science \& Medicine, 52(11), 1709-1718. 